\title{
Chemical Characteristic of 'Chao teri' As Traditional Fermentation Product
}

\author{
Syahriati ${ }^{*},{ }^{2}$, Amran Laga ${ }^{3}$, Mulyati M.Thahir ${ }^{3}$, dan Zaraswati Dwyana ${ }^{4}$
}

${ }^{*}$ Doctoral Student of Agricultural Sciences, Postgraduate Hasanuddin University (UNHAS), Makassar, Indonesia

${ }^{2}$ Lecturer of State Agricultural Polytechnic of Pangkep, South Sulawesi

${ }^{3}$ Department of Agricultural Technology, Faculty of Agricultural, Hasanuddin University (UNHAS), Makassar, Indonesia

${ }^{4}$ Department of Biology, Faculty of Mathematics and Nature Science, Hasanuddin University, Makassar, Indonesia

\begin{abstract}
'Chao teri' is a traditional fermented fish product of South Sulawesi as produced from the fermentation process of fish-carbohydrate-salt. It has characteristic like pasta, light-brown, distinctive and unique flavor, slightly acidic and salty taste. It is generally consumed by the local community as a complement dish or used as a flavor enhancer. This research aimed to analyze the chemical components of traditional 'Chao teri' includes $\mathrm{pH}$, total lactic acid, protein and amino acid profile. These chemical components were very contributes to the formation of flavor for traditional 'Chao teri'. The results of research are expected to be a reference for the industry to develop 'Chao teri'products into seasonings. Chemical characteristics of traditional 'Chao teri' after 2 weeks fermentation obtained $\mathrm{pH}$ 6.35, lactic acid $1.20 \%$ and protein $21.15 \%$. The analysis of amino acids indicated that traditional 'Chao teri' contains complete essential and non-essential amino acids. The type of dominant amino acid found in traditional 'Chao teri' are glutamic acid, leucine, aspartic acid and lysine.
\end{abstract}

Keywords: 'Chao Teri', Traditional Fermentation, Chemical Characteristics

\section{INTRODUCTION}

Fish is one of the fisheries commodities known as sources of animal protein which has high nutritional value. Fish protein is more easily digested and contains complete and balanced essential amino acids; therefore it is seen as having an important role in providing animal protein to improve the nutritional status of the community. On the other hand, fishery commodities generally have a short shelf-life, due to perishable nature. Various methods of fish processing that have been performed include salting, drying, smoking and fermentation.

Fermentation in fishery products is a traditional preservation technology in Indonesia and other Southeast Asian countries, where the process is relatively easy and inexpensive (Rahayu et al., 1992). In Indonesia, fermented fish products usually have special consumers in term of their ability to provide certain unique characteristics, especially for aroma, flavor and texture. Aroma and flavor that arises 
during the fermentation process will characterize the fermented fish products and be an attraction for consumers to consume it. According to Irianto (2008), the unique characteristics possessed by fermented fish products are generally determined by the type of fermentation of the product. The types of fermentation that are commonly found in the processing of fermented fish products in Indonesia are fish-salt and fish-salt-carbohydrate fermentations.

The success of producing unique characteristics in salt-fish fermentation is largely determined by the role of salt in selecting fermentative microorganisms. Examples of this fermentation are peda fish, shrimp paste, fish sauce and breed jambal. The type of fishsalt-carbohydrate fermentation is not only using salt but carbohydrates. Carbohydrates during fermentation will be decomposed into simple sugars and then converted to alcohol and acids which act as preservatives and give specific flavor and aroma to fermented fish products. An example of a type of fish-salt-carbohydrate fermentation is bekasam and chao.

Chao is one of the processed products of traditional fish in South Sulawesi, especially in Pangkep district, which is produced from the fermentation process of fish-carbohydrate-salt. Generally, the kind of fish used as raw material for making chao is anchovy so that traditional processors and local communities are more familiar with the term chao teri

The fermentation process of 'Chao teri' is done spontaneously with 2 (two) stages of fermentation namely salt fermentation (7 days) and carbohydrate fermentation (7 days), fermentation is done in a closed container at room temperature. The use of salt in the first fermentation stage is intended to inhibit the growth of bacteria, prevent the formation of ammonia from nitrogen compounds and to select microbes, the concentration of salt used in fermented
'Chao teri'i s 20-25\%. The second fermentation stage is done by adding $20 \%$ rice as a source of carbohydrates and $10 \%$ yeast. Carbohydrates are deliberately added to the container to be used as an energy source by microorganisms that will play a role in the fermentation process of fish meat. The addition of carbohydrates aims to stimulate the growth of lactic acid bacteria.

'Chao teri' is usually consumed as a complement dish that preserved with mango pickles and stone banana, or used as a flavor enhancer. It has a characteristic like paste, light-brown, distinctive flavor, slightly acidic and salty taste. Acidic taste that arises is caused by the presence of lactic acid bacteria that break down rice during fermentation.

Some chemical components related to the taste of 'Chao teri' such as $\mathrm{pH}$, total lactic acid, protein and amino acid profile have never been studied, so in this research an analysis is needed to determine the chemical components. The results of research are expected to be a reference for the industry to develop 'Chao teri'products into seasonings.

\section{METHODS AND MATERIAL}

\section{A. Preparation of sample}

Sample of 'Chao teri' that will to be analyzed was obtained from a traditional processor in Pundata Baji village, Labbakkang subdistrict, Pangkep district, South Sulawesi. 


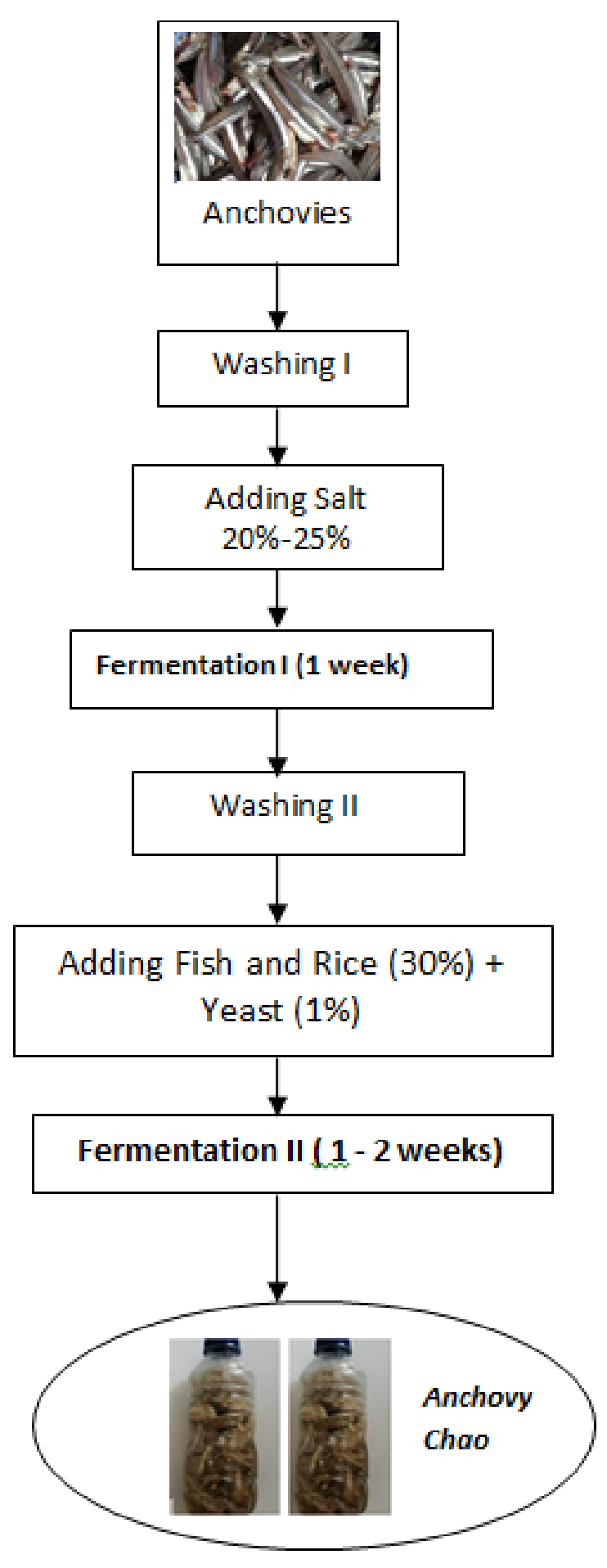

Figure 1. Flowchart for making 'Chao teri'

The process of making traditional 'Chao teri'begins with cleaning fresh anchovy which includes head separation and washing. Furthermore, washed anchovies were sprinkled with $20-25 \%$ salt, and then fermented in a closed container for a week
(Fermentation I). After salt fermentation process, the anchovy is washed again, drained for further addition $20 \%$ rice as a source of carbohydrates and $1 \%$ yeast. This mixture is stirred evenly and put in a closed container again for fermentation II for 1-2 weeks. The flow chart of making 'Chao teri'can be seen in Figure 1.

\section{B. Analysis Procedure}

1) $\mathrm{pH}$ measurement (AOAC, 1995) $\mathrm{pH}$ measurement of 'Chao teri'was conducted using a $\mathrm{pH}$ meter (Mettler Toledo Delta, USA). The first, $\mathrm{pH}$ meter is turned on, and then $\mathrm{pH}$-meter electrode is inserted in the buffer $\mathrm{pH} 4.31$ and 6.86. The sample was weighed as much as 1 gram, then dissolved in 10 $\mathrm{ml}$ of distilled water and put into a measuring cup. After that the electrodes are dipped in the sample solution and left for a while until a stable reading is obtained. The value obtained from the results of the reading on the $\mathrm{pH}$ meter until the digital number shows a fixed $\mathrm{pH}$ value.

2) Lactic Acid (AOAC, 1995)

A total of 10 grams of sample was crushed using mortar. Homogeneous samples were dissolved with distilled water in a beaker glass to a mark of $100 \mathrm{ml}$. Then, the sample is allowed to stand for 30 minutes and stirred. The solution containing the sample is filtered and piped $10 \mathrm{ml}$ to be put into the beaker glass. Phenophthalein $2-3$ drops are added to the solution and titrated with $0.1 \mathrm{~N} \mathrm{NaOH}$ until the color turns pink. The percentage of lactic acid formed is calculated according to the formula:

$$
\text { Total Lactic Acid }(\%)=\frac{a x b x c b d}{e} x 100 \%
$$

Where:

$\mathrm{a}=$ Amount of $\mathrm{NaOH}$ needed in titration $(\mathrm{ml})$

$\mathrm{b}=\mathrm{NaOH}$ normality $(0.1 \mathrm{~N})$

c $=$ Equivalent weight of lactic acid (90) 
$\mathrm{d}=$ Dilution factor (10)

$\mathrm{e}=$ Sample weight $(\mathrm{mg})$

\section{3) Protein Content (BSN, 1992)}

In this research, analysis of protein content refers to SNI 01-2891-1992 point 7.1. It was done to determine the crude protein content of an ingredient. The principle of this analysis is that nitrogen compounds are converted to ammonium sulfate by concentrated $\mathrm{H}_{2} \mathrm{SO}_{4}$. Ammonium sulfate formed is decomposed with $\mathrm{NaOH}$. Released ammonia is bound with boric acid, and thentitrated with a standard acid solution.

The sample was weighed as much as $0.51 \mathrm{~g}$, and then put into a $100 \mathrm{~mL}$ Kjeldhal tube. As much as $2 \mathrm{~g}$ selenium is put into a tube and $25 \mathrm{~mL}$ of concentrated $\mathrm{H}_{2} \mathrm{SO}_{4}$ is added. The tube containing the solution is heated to boiling and the color of the solution becomes clear green (about 2 hours). The sample is cooled and diluted by adding distilled water up to 100 $\mathrm{mL}$ to the measuring flask. Then, the solution was pipetted as much as $5 \mathrm{~mL}$ and put into a distillator, then added $30 \% \mathrm{NaOH}$ solution as much as $5 \mathrm{~mL}$ and a few drops of phenolptalein indicator.

Distillation is conducted for approximately 10 minutes. The liquidin the condenser tube is accommodated in an erlenmeyer containing $10 \mathrm{~mL}$ of $2 \% \mathrm{H}_{3} \mathrm{BO}_{3}$ and 3 indicator drops (methyl red and bromcresol green liquids) which are under the condenser. The tip of the cooler is rinsed with distilled water. The sample is then titrated using $0.01 \mathrm{~N} \mathrm{HCl}$ until the color of the solution turns pink again. Calculation of protein content can be performed by using the formula as follows:

$\% \mathrm{~N}=\frac{m l \mathrm{HCl}(\text { sample-blanko }) \times N \mathrm{HCl} \times 14,008 x \mathrm{FP}}{\text { sample weight }(\mathrm{g}) X 1000} X 100 \%$

$\%$ Protein $=\% \mathrm{~N} x$ conversion factor of fish protein $(6,25)$.
4) Amino Acid (HPLC)

Amino acid content was analyzed by using HPLC (waters corporation, USA). Amino acid standard solution was used for calibration from AccqTag, Thermo Scientific (3.9 x $150 \mathrm{~mm})$, temperature 370C, and mobile phase of acetonitrile 60\% -Accq Tag Fluent A. Flow rate of $1.0 \mathrm{ml} / \mathrm{min}$ with a fluorescence detector. The injector volume for each sample is $5 \mu \mathrm{L}$. A total of $0.1 \mathrm{~g}$ of sample was added with $5 \mathrm{ml}$ of $\mathrm{HCl}$ $6 \mathrm{~N}$, then vortex. Hydrolysis was done at $1100 \mathrm{C}$ for 22 hours. After hydrolysis, it is cooled and then transferred to a $50 \mathrm{ml}$ volumetric flask and aquabidest added to the limit mark. The solution was filtered with a $0.20 \mu \mathrm{m}$ filter.

The filtrate was pipetted $500 \mu \mathrm{l}$ plus $40 \mu \mathrm{m}$, AABA and approximately $460 \mu \mathrm{l}$ aquabidest. This solution was then pipetted as much as $10 \mu \mathrm{l}$ plus $70 \mu \mathrm{l}$ AccQFluor A, in the vortex and allowed to stand for 1 minute. The solution was incubated for 10 minutes at a temperature of 550C, and then it was injected into the HPLC system.

\section{RESULTS AND DISCUSSION}

Chemical characterization of 'Chao teri' as traditional fermentation result includes the measurement of $\mathrm{pH}$, lactic acid (\%), protein (\%), volatile aroma compounds and amino acid analysis. The analysis result of $\mathrm{pH}$, lactic acid (\%), protein (\%)can be seen in Table 1.

Table 1. Analysis result of $\mathrm{pH}$, lactic acid and protein

\begin{tabular}{|l|c|}
\hline \multicolumn{1}{|c|}{ Parameter } & Value \\
\hline $\mathrm{pH}$ & 6,35 \\
\hline Total lactic acid (\%) & 1,20 \\
\hline Protein (\%) & 21,15 \\
\hline
\end{tabular}

A fermentation process of 'Chao teri' which lasted for 2 weeksresulted in $\mathrm{pH}$ 6.35, lactic acid $1.20 \%$ and protein $21.15 \%$. This result is not much different 
from the results of some 'Chao teri'-like fermentation product such as "Plara" (fish paste from Thailand), has a protein content of $11.61-23.32 \%, \mathrm{pH} 4.10-6.90$ and acid lactate $0.17-1.94 \%$. "Burongisda" (fish paste from Philippines), fermented for one week, resulted in lactic acid $0.9 \%$ and $\mathrm{pH}$ about 4.0 (Rahayu et al., 1992). "Rusip" produced from anchovies fermented for 1-2 weeks resulted in $\mathrm{pH}$ 5.61, lactic acid 2.28\% and protein $14.45 \%$ (Koesoemawardani et al., 2017).

According to Mueda (2015), $\mathrm{pH}$ value of fermented fish sauce products is a very important characteristic to identify between good and poor quality fish sauces. The value of $\mathrm{pH}$ of traditional 'Chao teri' $(\mathrm{pH}$ 6.35) as produced is almost the same as $\mathrm{pH}$ of processed fish which ranges from 6.7 (Mizutani et al., 1992), and still meets the requirements of SNI-01-4271-1996. The Tropical Product Institute of United Kingdom recommends the best $\mathrm{pH}$ for fish sauce is 5.8 , while from Food Specifications and Standards, Myanmar recommends $\mathrm{pH}$ for fish sauce ranges from 6.0 - 7.5 (Yap and Lin, 1986). Codex Alimentarius (2013) stipulates that the standard $\mathrm{pH}$ for fish sauce products is $5.0-6.5$.

During fermentation, the source of carbohydrates used in making 'Chao teri'will be broken down by lactic acid bacteria into organic acids including lactic acid. The lactic acid produced will lower the $\mathrm{pH}$ and give acidity to 'Chao teri'. Based on the end result of glucose metabolism, lactic acid bacteria are divided into 2 (two) groups, namely lactic acid bacteria that only produce lactic acid in glucose fermentation and classified as homofermentative group. Homofermentative bacteria can break down glucose into lactic acid through Embden-Meyerhorf-Parnas (EMP) pathway or glycolysis. The enzymes that play a role in the glycolysis stage are aldolase enzyme and hexose isomerase. Heterofermentative lactic acid bacteria are able to break down glucose into lactic acid, acetic acid, propionic acid, CO2 and ethanol through the oxidative pentose phosphate pathway with the help of phosphoketolase enzyme.

Protein content of traditional 'Chao teri' is $21.15 \%$. Lopetcharat et al. (2007) explained that fish protein which is a complex compound, during fermentation will be hydrolyzed into simpler compounds. Protein breakdown results are a source of many compounds that will affect food sensory. Most of fish protein except connective tissue and other stromal proteins will be hydrolyzed into amino acids and peptides, and then amino acids will be further decomposed into other components that play a role in the formation of aroma and product flavor.

Amino acid content of fermented fish products is greatly contributes to the aroma and flavor. In the process of fish maturation, many biochemical changes occur including decomposition of proteins and fats. Proteolysis as occur during the fermentation process of fish is assumed to have caused peptides and amino acids which may undergo various changes through deamination, decarboxylation, and transamination to produce amines, keto acids, ammonia and CO2. Beddows et al. (1979) explained that the availability of amino acids is important at proteolysis stage in aroma formation. Amino acids can be used as substrates by bacteria for transformation or synthesis of flavor compounds. The analysis result of amino acid content of traditional 'Chao teri'can be seen in Table 2.

Table 2. Analysis result of amino acid

\begin{tabular}{|l|c|}
\hline \multicolumn{1}{|c|}{ Amino Acid } & Total $(\mathrm{mg} / \mathrm{kg})$ \\
\hline Tyrosine & 6004,81 \\
\hline Glutamic Acid & 28099,41 \\
\hline Serin & 7240,61 \\
\hline Tryptophan & 1541,43 \\
\hline Methionine & 5308,47 \\
\hline
\end{tabular}




\begin{tabular}{|l|r|}
\hline Cysteine & 262,65 \\
\hline Histidine & 5210,36 \\
\hline Threonin & 8631,04 \\
\hline Proline & 6620,92 \\
\hline Phenylalanine & 8880,63 \\
\hline Leucine & 14070,65 \\
\hline Aspartic acid & 12303,28 \\
\hline Lysine & 12992,46 \\
\hline Glycine & 9462,61 \\
\hline Arginine & 8894,49 \\
\hline Alanin & 10019,70 \\
\hline Valine & 9623,63 \\
\hline Isoleucine & 8574,53 \\
\hline
\end{tabular}

(Dincer et al., 2010). Shottsuru, Japanese fish sauce contains glutamic acid $721.8 \mathrm{mg} / 100 \mathrm{~mL}$, and lysine 451 - $581 \mathrm{mg} / 100 \mathrm{~g}$ (Beddows et al., 1985). Mclver et al. (1982) reported that glutamic acid, lysine and alanine were the most dominant amino acids found in Chinese fish sauce, Yeesui. Sikorski et al. (1990) reported that glycine, alanine, serine and threonin give a sweet flavor, arginine, leucine, phenyl alanine, histidine and isoleucine give a bitter flavor, while glutamic acid gives the impression of meaty, umami taste and delicious on fish sauce products.

\section{CONCLUSION}

The analysis of amino acid (Table 2) shows that traditional 'Chao teri' contain complete essential and non-essential amino acids. The essential amino acids of traditional 'Chao teri' are valine, leucine, isoleucine, threonin, methionine, phenylalanine, arginine, lysine, histidine and tryptophan. Leucine and lysine amino acids are in quite a lot, namely $14070.65 \mathrm{mg} / \mathrm{kg}$ and $12992 \mathrm{mg} / \mathrm{kg}$, respectively. Essential amino acids are essential for body growth so that the fulfillment of essential amino acids can be obtained from 'Chao teri'.

Non-essential amino acids of 'Chao teri' are tyrosine, glutamic acid, serine, tryptophan, cysteine, proline and aspartic acid. The most abundant amino acids found in traditional 'Chao teri' are glutamic acid (28099.41 mg/kg), then leucine (14070.65 mg/kg), lysine $(12992.46 \mathrm{mg} / \mathrm{kg})$, aspartic acid $(12303.28$ $\mathrm{mg} / \mathrm{kg}) \mathrm{kg}$ ) and alanine $(10019.70 \mathrm{mg} / \mathrm{kg})$. Some 'Chao teri'-like fermented fish products such as Bakasang also have high glutamic acid content besides alanine, isoleucine and lysine (Ijong and Ohta, 1996). The most dominant amino acids found in Patis, fish sauce from the Philippines are glutamic acid $831 \mathrm{mg} / 100 \mathrm{~mL}$, alanine, linin and aspartic acid are also found in high amounts after glutamic acid

Chemical characteristics of traditional 'Chao teri' after 2 weeks fermentation obtained $\mathrm{pH}$ 6.35, lactic acid $1.20 \%$ and protein $21.15 \%$. The analysis result of amino acid showed that traditional 'Chao teri' contain complete essential and non-essential amino acids. The types of dominant amino acid found in traditional 'Chao teri' were glutamic acid, leucine, aspartic acid and lysine.

\section{REFERENCES}

[1] AOAC,1995. Official Methods of Analysis. Virginia: The Association of Official Analytical and Chemist. 16 thed. Arlington. AOAC Inc.

[2] Badan Standar Nasional, 1992. Cara Uji Makanan dan Minuman. SNI 01-2891-1992

[3] Beddows,C.G.andArdeshir,A.G.1979. The Production of Soluble Fish Protein Solution for Use in Fish Sauce Manufacture. J.FoodTechnol.14,603-612.

[4] Beddows, C.G.1985. Fermented Fish and Fish Products.In Wood, B.J.B.(ed). Microbiology of Fermented Foods. Vol .2. Elsevier Applied Science.London. 
[5] Codex Alimentarius, 2013. Standard for Fish Sauce (CODEX STAN 302-2011). www.codexalimentarius.org/input/download/s tandards/11796.

[6] Dincer, T., Cakli, S.,Kilinc, B and Tolasa, S. 2010. Amino Acids and Fatty Acid Composition Content ofFish Sauce. Journal of Animal and Veterinary Advances 9(2):311315. DOI:10.3923/javaa.2010.311.315.

[7] Ijong, F.G. and Ohta, Y. 1996. Physicochemical and microbiological changes associated with bakasang processing-a traditional Indonesian fermented fish sauce. Journal of Science Food Agriculture71: 69-74.

[8] Irianto, H.E. 2008. Produk Ikan Fermentasi Tradisional Indonesia. Balai Besar Riset Pengolahan Produk dan bioteknologi Kelautan dan Perikanan. Jakarta.

[9] Koesoemawardani, D., S.Hidayati and Subeki.2017. Amino acid and fatty acid compositions of Rusip from fermented Anchovy fish (Stolephorus sp).IOP Conference Series:Materials Science and Engineering 344(2018). Doi:10.1088/1757899X/344/1/012005

[10] Lopetcharat, K., Choi, Y.J., Park, J.W and Daeschel, M.A. 2002. Fish Sauce Products and Manufacturing: a Review, Food Reviews International. 17(1).

[11] McIver, R.C., R.I. Brooks and G.A. Reineccius. Flavor of Fermented Fish Sauce. J.Agric.Food Chem.,Vol 30. No.6

[12] Mizutani, T., A. Kimizuka., K. Ruddle and N. Ishige. 1992. Chemical Component of Fermented Fish Products. Journal of Food Composition and Analysis 5,152-155

[13] Mueda, R.T. 2015. Physico-chemical and color characteristics of salt- fermented fish sauce from anchovy Stolephorus
commersonii.International Journal of the Bioflux Society. Volume8, Issue 4.

[14] Rahayu W.P., Ma'oen, S, Suliantari dan Fardiaz S. 1992. Teknologi Fermentasi Produk Perikanan. Bogor: Pusat Antar Universitas Pangan dan Gizi. Institut Pertanian Bogor.

[15] Sikorski, Z.E., Kolakowska, A and Pan, B.S. 1990. The Nutritive Composition of The Major Groups of Marine Food Organisms. In: Sikorski,Z.E., (Ed.), Seafood: Resources, Nutritional Composition, and Preservation. Florida: CRC Press, Inc. pp.29-54.

[16] Yap P., KuoY.L., 1986. Fish sauce quality and standardization. In: Proceedings of the 1st Asean workshopon Fish and Fish Waste Processing and Utilization.

\section{Cite this article as :}

Syahriati, Amran Laga, Mulyati M. Thahir, Dan Zaraswati Dwyana, "Chemical Characteristic of 'Chao teri' As Traditional Fermentation Product", International Journal of Scientific Research in Science and Technology (IJSRST), Online ISSN : 2395-602X, Print ISSN : 2395-6011, Volume 6 Issue 4, pp. 160-166, July-August 2019. Available at doi : https://doi.org/10.32628/IJSRST196430 Journal URL : http://ijsrst.com/IJSRST196430 